\title{
A counseling service for developing the qona'ah attitude of millennial generation in attaining happiness
}

\author{
Al Halik* \\ Institut Agama Islam Negeri Metro, Lampung, Indonesia \\ Email: alhalik6@gmail.com
}

\begin{abstract}
Purpose - The research objective is a trial to create group counseling services with self-acceptance techniques to develop Qona'ah attitudes in realizing the happiness of the millennial generation.

Method - The method used in data collection was a literature study.

Result - The result of this paper is to offer group guidance and counseling using self-acceptance techniques to develop a Qona'ah attitude. Positive selfacceptance will be able to create happiness.

Implications - Qona'ah attitude requires a training with strong patience, the applied counseling services aregroup guidance and counseling services with four stages.

Originality - A method of developing the Qona'ah attitude of the millennial generation is a process of providing professional assistance which is characterized by a continuous process with systematic steps to an individu or groups of people.
\end{abstract}

Keywords: Qona'ah, happiness, millennial generation.

For citation: Halik, A. (2020). A counseling service for developing the qona'ah attitude of millennial generation in attaining happiness. Journal of Advanced Guidance and Counseling. 1(2). 82-100. https://doi.org/10.21580/jagc.2020.1.2.5810.

*Corresponding author: Al Halik (alhalik6@gmail.com), Institut Agama Islam Negeri Metro, Jalan Ki Hajar Dewantara No.15A, Iringmulyo, Kec. Metro Tim., Kota Metro, Lampung 34112. 
A counseling service for developing the qana'ah attitude of millennial generation in attaining happiness

\begin{abstract}
Abstrak
Tujuan - Tujuan penelitian ini adalah uji coba untuk menciptakan layanan konseling kelompok dengan teknik penerimaan diri untuk mengembangkan sikap Qona'ah dalam mewujudkan kebahagiaan generasi milenial.

Metode - Metode yang digunakan adalah studi pustaka.

Hasil - Hasil dari penelitian ini adalah menawarkan bimbingan dan konseling kelompok menggunakan teknik penerimaan diri untuk mengembangkan sikap Qona'ah. Penerimaan diri yang positif akan mampu menciptakan kebahagiaan.

Implikasi-Sikap Qona'ah membutuhkan pelatihan dengan kesabaran yang kuat, layanan konseling yang diterapkan adalah layanan bimbingan dan konseling kelompok dengan empat tahap.

Orisinalitas - Metode pengembangan sikap Qona'ah generasi milenial melalui proses pemberian bantuan profesional yang bercirikan proses berkelanjutan dengan langkah-langkah sistematis kepada individu atau kelompok masyarakat.
\end{abstract}

Kata kunci: Qona'ah, Kebahagiaan, Generasi Milenial

\title{
Introduction
}

Nowadays, technological advances create an interesting phenomenon in people's lives, namely the development of an instantaneous lifestyle in the midst of a global culture. In the process, a new generation was born, commonly known as the gadget generation. This term is caused by the impact of the unstoppable flow of globalization, so that the gadget generation is a sign of the emergence of the millennial generation (Ali \& Purwandi, 2017). The word, "gadget", is more accurately defined as a piece of equipment, which means the generation that lives side by side and uses information technology equipment. As if this technology equipment could not be separated from their lives. In the other word, the millennial generation is a generation of information technology users who make themselves easier to find information by just accessing the internet.

According to the 2017 National Socio-Economic Survey, millennials are the largest population group, namely, $33.7 \%$ or around 88 million (Budiati et al., 2018). Most of them live in urban areas (Budiati et al., 2018), for example, in DKI Jakarta, the percentage of young population reaches 40\% (Ali \& Purwandi, 2016). Generally, rural communities have begun to shift to urban communities. This shift has an impact on changes in culture, social values, behavior and people's mindset. 
Al Halik

The traditional values are being faded away by urban culture, people who are grouped into individual societies, which used to be simple at first, become a consumptive society, the traditional mindset has been starting to open up and JAGC | 84 modern (Budiati et al., 2018).

Millennials who grow up in the midst of strong technological developments make their attitudes and behavior influenced by gedget and the internet. They tend to prioritize the use of technology such as gedget, which can spend 1-6 hours a day or nearly 40 hours per week to access the internet. (Ali \& Purwandi, 2017). In addition, the tendency for their moral identity to prioritize musical tastes, trendy lifestyles, and the pursuit of pleasure (being hedonistic), make them become consumptive or have high purchasing power. In religious life, the millennial generation tends to be individualistic and puts material above everything else (Putu \& Ketut, 2017).

Material fulfillment makes life more competitive among millennial generations. They struggled to the best of their ability, even continuing to work indefinitely. This tendency makes it difficult for them to determine what actions should be done and what actions are right. This case results in frustration that in the end, there is no interest, reduced ability to make decisions or take initiatives, and feelings of unhappiness because life feels empty. The health foundation study states that the millennial generation is an unhappy and less healthy generation than the previous generation. Even millennials aged 20 to 30 have a lot of difficulties from home to work (Juniman, 2018). Their struggle to obtain material, of course, is to meet their needs, but the lack of fulfillment of needs can make them restless, filled with anxiety, unsettled, and unhappy in life.

Happiness is relatively in accordance with the goals of the person who is looking for it, because happiness is a feeling of pleasure that is achieved according to the wishes and needs of each person. The problem is how people have to interpret this word happily appropriately, so that with the right concept people can choose the best way to achieve it, especially in this modern era. Modernization with the offered products has brought great benefits to human life. However, one thing that brings worry for many people who have experienced the negative impact of modern life patterns is a crisis in human spirituality. Nata predicts that 
A counseling service for developing the qana'ah attitude of millennial generation in attaining happiness

humans will tend to act freely by ignoring spiritual, moral, and religious foundations (Nata, 2018). The ethos of materialism, consumerism, and focus on technology makes children lose awareness of their primary life.

One of the efforts to maintain the positive aspect of modernism and fill the gaps in it is to interpret Islam more fully and comprehensively by strengthening Islamic spirituality. Millennials view religion as a essential aspect, because they believe that religion is important for carrying out daily life (Naja, 2018). The World Gallup Poll survey also found that $92 \%$ of individuals in thirty-two developing countries stated the importance of religion in their daily lives. (Firmansyah, 2018). A number of studies delineate that religious / spiritual attitudes have better health and adapt quickly to problems compared to those who are less religious / spiritual, and spiritual-religious can affect mental and physical health (Koenig, 2012). On the other hand, one of the ways to get happiness is by studying religion / spirituality.

Jalaludin in his book states that religion is one of the factors for self-control, religion is absolutely needed as a certainty of norms and demands for a healthy and right life. Religion is a psychological necessity, because living by a set of rules, morals, ethics, and spiritual values can make the mental state balanced, healthy, and make the soul peaceful. (Jalaluddin, 2004). The teachings of all religions, including Islam, teach to prioritize faith which leads to: having an attitude of receiving with gratitude and pleasure known as Qona'ah. The form of Qona'ah attitude is that someone feels sufficient, not greedy, and not jealous of other people's sustenance and seeks sustenance in a lawful way. With this attitude, a person will feel satisfied, calm, and sufficient with what he has. The attitude of Qona'ah is often unstable, many individuals in modern times are impatient with accept life's problems to despair.

Qona'ah is one of the teachings of Sufism, where this teaching can be a solution and therapy or psychotherapy for modern-day problems. Using the dimensions of religion and spirituality in psychotherapy appropriately can provide change, hope, and enlightenment in the individual (Firmansyah, 2018). Developing a Qona'ah attitude is able to overcome anxiety of inability to meet needs, worry about other people's judgments, worry about the future, worry about not being able to solve problems, and worry about not being able to meet family needs. Therefore that 
Al Halik

the teachings of Sufism such as Qona'ah can be a way or solution to solve problems and get happiness.

A happy individual is an individual who feels satisfied with his life and rarely JAGC | 86 feels unpleasant emotions such as sadness or anger. To know a happy individual, we can ask him to explain his feelings about himself and the environment. In the psychology aspect related to happiness, it is known as well-being. According to Carol D. Ryff, people who are happy and have life satisfaction are characterized by the absence of depressive symptoms and can lead a positive life. Furthermore, it is explained that the individual happy and has a positive pyschology is characterized by: self-acceptance, positive relationships with others, independence, ability to achieve life goals, ability to develop potential, and control of the environment (Keyes et al., 2002).

In this case, the use of counseling services is needed to develop a Qona'ah attitude in attaining happiness. According to Ali, basically the Qona'ah attitude is representative of acceptance and satisfaction with what is owned and achieved. Qona'ah also acts as a means of dealing with social and environmental problems (Ali, 2014). Counseling services will focus on increasing self-acceptance of the millennial generation. Research by Nuryono states that narrative counseling is effective in increasing student self-acceptance (Nuryono, 2012). There is an effect of increasing the understanding of Qona'ah values through group guidance with group discussion techniques on increasing self-esteem (Ani, 2016). This step provides an opportunity to develop the potential to avoid life's crises by maintaining a spiritual basis so that life becomes balanced, because life is a process of maintaining the purity of the heart from bad deeds (immorality).

Counseling service, as a method of developing the Qona'ah attitude of the millennial generation, is a process of providing professional assistance which is characterized by a continuous process with systematic steps to an individu or group of people. In the other word, a person can understand himself and independently be able to alleviate the problem. Likewise that a person can run a harmonious life, namely happiness in this world and in the hereafter. This step refers to the objectives of Islamic counseling, namely, the effort to manifest the individual as a 
A counseling service for developing the qana'ah attitude of millennial generation in attaining happiness

whole, human being to achieve world and lasting happiness (Faqih, 2001). Finally, the purpose of the counseling service is to help create a happy life.

\section{Results and Discussion}

Happiness is a positive emotion which sometimes the form of it can only be seen through explicit expression. Mayasari stated that individuals who have high happiness are characterized by life satisfaction, avoiding unpleasant emotions such as sadness and anger. Conversely, unhappy people are prone to dissatisfied with what they get, feel unhappy, irritable, and worry constantly (Mayasari, 2014). According to Dinner, based on research, we found that happy people have a lot of positive emotions and few negative emotions have and are involved in enjoyable activities, and are satisfied with their lives (Rahardjo, 2007). In addition, Carol D. Ryff said that people who are happy and have life satisfaction are characterized by the absence of depressive symptoms and can lead a positive life (Keyes et al., 2002). In the official Bahasa Indonesia dictionary, for example, the joy of feeling is that there is pleasure and peace of life both physically and mentally. The happiness can be so subjective and different for each individual, it is influenced by the goals and indicators to be achieved and pursued.

In human efforts to achieve happiness, they often encounter obstacles, even mistakenly distinguishing between obtaining pleasure and happiness. Therefore, many humans are found trapped in pleasure that does not give a feeling of happiness. Especially in the midst of the current development of globalization which affects the rapid shift in the values of life and has an impact and change on humans. This shift has an impact on changes in culture, social values, behavior, and people's mindset. Traditional values are slowly being eroded by urban culture, communities that are grouped into individual societies, which used to be simple have become consumptive societies. In this case, the traditional mindsets of the people are starting to open up and modern (Budiati et al., 2018). As the impact of that, people today also face increasingly diverse problems, including educational, economic, social, family, and environmental demands, along with the desire to increase self-achievement. 
Al Halik

The generation that has grown up in the midst of the current development of technological globalization is called as millennial generation. Millennials is a generation of a group in productive age and become consumers who dominate JAGC | 88 the market nowasday (Ali \& Purwandi, 2016). As given data of BPS (Badan Pusat Statistik), The number of millennial generation in Indonesia aged 17-37 is 81 million (Budiati et al., 2018). Millennial generation is recognized as a unique generation, especially proficiency in using technology. The term "millennial" was coined by two American historians and writers, namely, William Strauss and Neil Howe, named the millennium generation because they felt the development of technology and the year turn of the millennium (Rifai, 2018). The proficiency in using technology has become a characteristic of the millennial generation due to the emergence of more rapid technologies such as smartphones, the internet, and social networks (social media) that affect the way of thinking, behavior and values.

Millennials who grow up in the midst of the strong current of technological development, make their attitudes and behavior much influenced by gedget and the internet. They tend to emphasize the use of technology such as gedget, in a day it can spend 1-6 hours or nearly 40 hours per week to access the internet (Ali \& Purwandi, 2017). Furtheremore, Bernardi in his research also stated that internet usage of the generation is up to 40 hours per week. The differences were found in the reasons for accessing the internet. Women tend to spend a lot of time chatting (talking to people), while men play games (Bernardi \& Pallanti, 2009).

The amount of time which is spent by accessing the internet turns out to have a bad impact on their psychology. Research conducted by Bambang describes the problems faced by the millennial generation, $80 \%$ face gadget addiction, so they cannot focus on studying disturbed emotions addicted to pornography, tend to be in contact with promiscuity. Furthermore, Bernardi also found that excessive internet use leads to increased social anxiety, feelings of emptiness, boredom, depressed mood, strong irritability, and sleep deprivation (Bernardi \& Pallanti, 2009). This means that the serious problems experienced by the millennial generation are related to communication technology, addiction to this gadget certainly affects behavior. Thus it is no wonder the easy access to information 
A counseling service for developing the qana'ah attitude of millennial generation in attaining happiness

through gadgets can be an indicator of why the millennial generation is falling for pornography and promiscuity.

Millennials have a tendency in their moral identity to prioritize musical tastes, and trendy lifestyles and pursue enjoyment (hedonism), high consumption, or purchasing power. In religious life, the millennial generation tends to be individualistic and puts material above everything else (Putu \& Ketut, 2017). The millennial generation tends to be proud of a freedom lifestyle, individualism, a lifestyle of pursuing pleasure (hedonism), as well as unrealistic visions and being idealistic. Bambang Suryadi pointed out the salient characteristics of the millennial generation, namely, individualistic attitude and easy boredom, ego-centric, being different and impatient (Bambang, 2015). Ali and Purwandi also stated that the middle class millennials are an individualist society and place material above everything (Ali \& Purwandi, 2017). This behavior makes them indifferent individuals in their religious life. They are more likely to look for concepts that match their individualistic characteristics. This situation will certainly have implications for the future of their religious life.

When a desire cannot be fulfilled, it can cause many problems. Material fulfillment makes life more competitive and creates a struggling attitude to give all efforts, even to continue working indefinitely. This tendency makes it difficult for people to determine what actions should be done and what actions are right. This case results a frustration which ultimately eliminates an interest, there is reduced ability to make decisions or take initiatives, and creates feelings of unhappiness because life feels empty. The health Foundation study states that the millennial generation is an unhappy and less healthy generation than the previous generation. Even millennials aged 20 to 30 have a lot of difficulties from home to work (Juniman, 2018). Their struggle to obtain material is of course to meet their needs, because the lack of fulfillment to the needs can make them restless, filled with anxiety and uneasiness and unhappiness in living life.

Modern individuals are encouraged to enhance themselves and strengthen the foundations of their psychological condition with activities of religious value. Spirituality in religious activities can be seen from the actions and behavior in daily life. Mayasari explained that spirituality is an important factor influencing individual 
Al Halik

religiousness. Spiritual what is meant is an experience of closeness to God, which can lead to obedience to His commands and stay away from His prohibitions (ritual aspects and consequences) (Mayasari, 2014). Tiliouine, Cummins and Davern in JAGC $\mid 90$ their research revealed that religiosity is a factor that affects well-being (happiness / welfare), and shows a strong positive relationship where religiosity provides (Tiliouine et al., 2009). This means that the attitude of Islamic teachings in daily behavior gives hope and fills individuals for their future and realizes a meaningful life.

Naja explained that the millennial generation views religion as something essential, because they believe that religion is an important thing for everyday life (Naja, 2018). The World Gallup Poll survey also found that $92 \%$ of individuals in thirty-two developing countries stated the importance of religion in their daily lives. (Firmansyah, 2018). Jalaludin stated that religion is a factor which is capable of selfcontrol, religion is absolutely needed as the assurance of norms and demands for a healthy and good life. Religion is a psychological necessity, because living by a set of rules, moral, ethical, and spiritual values can make a balanced, healthy and peaceful mental state (Jalaluddin, 2004). A number of studies show that someone who is religious / spiritual has better health and adapts quickly to problems compared to those who are less religious / spiritual and spiritual-religious itself can affect mental and physical health (Koenig, 2012). In the other word, one of the ways to obtain happiness is by instilling religious / spiritual values in life.

The weak level of spirituality of the millennial generation is the source of wrong behavior, especially for those who live in big cities often become addicts to drugs, tend to have bad relationships and free lifestyle, they get pleasure but are not happy. Nata predicts that humans will tend to act freely by ignoring spiritual, moral, and religious foundations (Nata, 2018). The ethos of materialism, consumerism, and focus on technology have made children lose their primary lives.

Rakhmat in his interpretation of happiness explains the steps in achieving happiness in the world and the hereafter, that are doing good deeds, believing that behind difficulties there must be ease, gratitude, pleasure and trust in the event of a disaster, apologizing for the mistakes of others, avoiding prejudice, avoiding the habit of getting angry when facing the problem of being hit by something, 
A counseling service for developing the qana'ah attitude of millennial generation in attaining happiness

developing zuhud and Qona'ah attitudes so that worldly desires can be reduced (Rakhmat, 2010). One of the positive attitudes that must be had in modern times in achieving happiness is the attitude of Qona'ah. From this attitude, it can be a motivation to continue to be grateful and be patient with the situation at hand.

Hamka explained that Qona'ah is a filter in human life, so that human is motivated not to tabzir (wasteful). Qona'ah also functions as a stabilizer and dynamic for a Muslim's life (Hamka, 2015). As a stabilizer, a person will always be graceful, at ease, feel rich, and well off, free from greed, because in essence wealth and poverty lie in the heart, not in the assets they have. Meanwhile, as a dynamist, it is shown that someone has inner strength that always encourages to achieve progress in life based on independence by depending on Allah SWT.

In language, Qona'ah means receiving enough, while in terminology, Qona'ah is receiving enough for the given sustenance and bestowed by Allah SWT, this can avoid feeling less or greedy. Amin Syukur stated that Qona'ah is to accept freely his sustenance, accompanied by an active attitude to keep on trying, even if he gets something in less amount, he will feel enough for what Allah has given him (Syukur, 2012). The form of Qona'ah is a feeling of being sufficient for his sustenance, not being acquisitive and being greedy, not being jealous of what other people have, and not being greedy by justifying any means of seeking wealth. The Qona'ah attitude that develops within the individual will implement a feeling of satisfaction, calm, and sufficient for what he currently has, and his mind is not jealous of other people's sustenance. (Hamka, 2015).

Hamka in his book Modern Sufism explains that there are five things that must be conducted and implemented to achieve a Qona'ah attitude, namely: accepting willingly what we have, asking Allah for an appropriate addition and doing an effort, patiently accepting God's provisions, putting trust in Allah, disinterested in the deception toward what the world shows (Hamka, 2015). Hamka's perspective becomes a controller for modern humans or the millennial generation to differentiate between wants and needs. Furthermore, Hamka explained that Qona'ah is simplicity, which means that the development of this increasingly advanced technology is not the main goal but as a forum to be closer to Allah SWT. 
Al Halik

Gamayanti said that the study of Qona'ah is about self-acceptance (Gamayanti, 2016), Likewise, Kusumaningsih said that people who cannot accept their strengths and weaknesses will make those individuals hate themselves and JAGC | 92 start to keep away from Qona'ah attitudes (Kusumaningsih, 2017). Furthermore, Carol D. Ryff stated that one of the indicators to indicate a happy person is marked by self-acceptance. The number of demands in life makes an individual unable to meet the demands, which makes him feel unhappy. According to Ali, basically the Qona'ah attitude is representative of the acceptance and satisfaction of what is owned and achieved. Qona'ah also acts as a means of dealing with social and environmental problems (Ali, 2014).

As the stated problems above, it is necessary to develop a Qona'ah attitude, because developing a Qona'ah attitude is able to overcome the anxiety of being unable to meet needs, worry about other people's judgments, worry about the future, worry about not being able to solve problems, and worry about not being able to meet family needs. Based on the research of Saputro, the results state that the higher the Qona'ah attitude, the higher the level of life satisfaction and reduce stress (Saputro et al., 2017). Syauqi Abdillah even stated that a lack of Qona'ah attitudes towards individuals can lead to anxiety and fear (Zein, 2017). Ali said that there are two aspects that can build qanaah, namely, a good life (hayatan thayyibah) and a willingness to accept (pleased) (Ali, 2014).

Syafi'ah in (Rahmadani et al., 2019) states that consumptive behavior causes a person to experience anxiety and a feeling of dissatisfaction with life. Happy individuals are individuals who feel satisfied with their lives and rarely feel unpleasant emotions such as sadness or anger. The results of the research by Rahmadani show that there is an influence of Qona'ah on consumptive behavior, if the qanaah attitude is high, the consumptive behavior will decrease. The nature of Qona'ah has an influence in controlling not to behave excessively or consumptive behavior (Rahmadani et al., 2019).

The results of that research indicate that Qona'ah is a form of psychotherapy in Islam. Psychotherapy is believed to be an alternative to solve life matters or problems. Firmansyah stated that psychotherapy utilizes religious and spiritual dimensions appropriately so that it can provide hope for change and 
A counseling service for developing the qana'ah attitude of millennial generation in attaining happiness

enlightenment in individuals. Abu Tauhid in Jalaluddin explains that religious guidance is an effort to develop and guide individuals optimally in dealing with the problems that occur within them according to Islamic teachings, in this case, the teachings are useful for themselves, environment, and society (Jalaluddin, 2004). In addition, Faqih explained that Islamic Religious Guidance is a process of assistance so that individual religious life is in harmony with Allah's instructions and provisions, So Individu can achieve the happiness of life in the world and the hereafter (Faqih, 2001).

Several studies have also explained that Islamic religious guidance with appropriate materials and that people's needs can strengthen self-acceptance (Ilma, 2019). Furthermore, Komariah stated that Islamic guidance and counseling was effective in increasing self-acceptance (Komariah, 2019). Some of the research results above show that Islamic guidance and counseling is effective in helping individuals overcome their problems. This is in accordance with the objectives of this program, which is to help individuals manifest themselves as whole humans, to achieve happiness in life in this world and the hereafter (Faqih, 2001).

The process of providing assistance is not only an individual, but it can also be applied in a group format. One type of Counseling Guidance services that can be used is group guidance and group counseling. Types of group guidance and group counseling services are able to create good relationships between group members, improve communication skills, trigger an understanding of various situations and environmental conditions, as well as develop attitudes. Samsul Munir explained that individual attitudes and values were easier to develop through group guidance (Amin, 2010). Nuryono stated that narrative counseling was effective in increasing students' self-acceptance (Nuryono, 2012). Counseling services will focus on increasing self-acceptance of the millennial generation.

The implementation of group guidance and group counseling can use a variety of approaches and techniques. Several studies have shown effective results, such as the results of Ani's research that group counseling with group discussion techniques provides increased Qona'ah values and self-esteem (Ani, 2016). The research of Sitorus also found that group guidance services with the play method 
Al Halik

can increase self-acceptance, and it is hoped that teachers will be able to implement these services (Sitorus et al., 2019).

In the research of Hasanah, group counseling with the approach of "Rational JAGC | 94 Emotive Behavior" or cognitive techniques can increase student self-acceptance (Hasanah, 2018). In addition, Putri explained that the Javanese culture-based reality group counseling such as "Nrimo ing Pandum" and "Sapa gawe akan nganggo", can be used to increase self-acceptance (Putri, 2018). Glasser (1998) argues that reality therapy and the choice of theory can be applied both individually and in groups to anyone with psychological problems in a cultural context (Putri, 2018). As Heryadi research results, individual reality counseling can increase students' low self-acceptance (Heriyadi, 2013).

Based on some of the findings above, as an effort to develop the Qona'ah attitude of the millennial generation in creating a sense of happiness, the author tries to offer types of group guidance and group counseling services that can be used as methods or approaches to develop self-acceptance (Qona'ah). Group guidance and group counseling are two types of Counseling Guidance services that are carried out in a group atmosphere characterized by the development and creation of group dynamics, the counselor as the group leader and the client as a group member. The group service process includes a process of disclosing and understanding problems, tracing the causes of problems, seeking solutions to problems and conducting evaluations and follow-ups that can be applied in everyday life effectively. Service orientation is to maintain and develop Qona'ah attitudes. The concept of Qona'ah is used as the material basis for the services provided, so that a person gets an understanding that a Qona'ah attitude can create happiness in the midst of a life that is full of competition.

The steps for creating Group Guidance and Counseling Guidance in developing Qona'ah attitudes in the millennial generation are the same as those used in counseling services in general. According to Prayitno, the implementation of group guidance and counseling services can be carried out in four stages as follows; the stage of formation, transition, main activity, and closing or the last step (Prayitno, 2017). The difference is only in the emphasis on the techniques used at the activity 
A counseling service for developing the qana'ah attitude of millennial generation in attaining happiness

stage, which is in accordance with the objectives. The steps to apply the technique from beginning until the self-acceptance process (Qona'ah) is complete, namely:

1. Identification of cases. It is a step to determine the symptoms and causes of problems faced by clients, both visible and invisible symptoms, so it requires deepening by carrying out the counseling process in disclosing it.

2. Diognosis. It refers to taking steps and making conclusions about the causes of client problems obtained through the previous counseling process (identification). Thus the diagnosis will get a conclusion such as:
a. The initial cause of the problems faced by clients,
b. The development of the problem since it arose until now,
c. The Specific complaints that are felt (whether it continues to grow or decrease),
d. Other factors that can affect the increase in client problems.

5. Prognosis. It is the step to determine the action to be given based on the cause of the problem and the factors. The steps for developing a Qona'ah attitude are carried out in accordance with Leo Babauta1 technique about self-

\footnotetext{
* Leo Babauta shared eight self-acceptance techniques, in which application can be added to the foundation of Islamic values, namely Al-Qur'an and hadith and the following eight techniques of self-acceptance: (1) "Relaxing awareness training" (contemplating what is on your mind and feeling and then welcome to express what you think and feel), (2) "Welcome, what you pay attention to" (after thoughts and feelings), feelings arise, then at this stage it is directed to learn how to respond to thoughts and feelings in moderation), (3) "Letting go of self-assessments" (inviting to avoid and discard negative judgments about oneself and comparing oneself with others, can be helped through dhikr, trust and be pleased with Allah's provisions, (4) "Thank you technique session" (inviting to think about what has been gained gratefully), (5) "Loving and forgiving oneself" (believing that what has been done is an effort that has been fought, even though there are still shortcomings and mistakes then give forgiveness to yourself). (6) "Learning from all parts" (inviting clients to believe, whatever is gained, both good and bad experiences, is something that should be learned and is able to find good values that bring happiness), (7) "Separating from emotions" (encouraging clients to let go of negative emotions, believing that it is not a part of themselves that should be followed, and (8) "Sharing to someone" (talking to people about hidden emotions and thoughts (with parents, siblings, teachers, friends, spouses, etc.), can help better understand oneself.
} 
Al Halik

acceptance. At each stage, the client will be asked to (1) create a comfortable position, (2) be able focus and concentration, (3) take breathe slowly and regularly, (4) to relax meditation.

JAGC | 96

6. Treatment. It is a step in the implementation of assistance according to prognostic steps. The implementation of this technique takes into account the suitability of the problem, the client's situation, and the environmental situation and other factors, so that the treatment process runs as expected. In the implementation of Group Guidance and Counseling, Guidance aims to train clients to develop Qona'ah attitudes starting from self-acceptance by changing their psychological state, especially their emotions and thoughts. In practice, the counselor gives instructions to the client, and the client follows these instructions. In accordance with the steps in the prognosis such as sitting comfortably and relax, taking a breath, continuing to reflect on what you feel and think (while spelling, the verses of Al-Qur'an, prayers, etc.) continue to be done, it is based on the Leo Babauta technique above.

7. Evaluation and Follow Up. This is a step to review and assess the extent to which the results of the counseling process have been effective and can solve someone's problems. The counselor continues to monitor the client's further progress.

Qona'ah is concerned with heart attitude or mental attitude. As Hamka said, Qona'ah has two meanings, namely, Zuhud and mental health (Hamka, 2015). Mental health is well due to in life it is filled with relief, pleasure, patience for facing the given problems, and gratitude for the received blessings. Thus that people can avoid the tense of fear, excessive sadness because people should believe that Allah's gift is the best, realizing that all will have rewards at the end. Therefore, AlGhazali explained that developing a Qona'ah attitude requires training with strong patience. In nafsiology, calm and tranquility can be manifested by training and education to change these behaviors. 
A counseling service for developing the qana'ah attitude of millennial generation in attaining happiness

\section{Conclusion}

Technological advances have led to interesting phenomena in the life of millennial generations today. This development triggers many perceived problems which result in psychological, educational, health, social and occupational changes, along with demands for self-development. The inability to meet needs results in frustration, loss of interest, lack of initiative, instablity and anxiety, feelings of sadness, depression, loneliness, hopelessness, and feelings of emptiness or unhappiness. The Efforts to overcome and avoid these problems are to obtain happiness by instilling gratitude for what has been obtained, namely, by developing a Qona'ah attitude or self-acceptance. The applied counseling services are group guidance and counseling services with four stages, namely, formation, transition, activity, and closure with steps that apply techniques from before until the self-acceptance process (Qona'ah) is complete, namely: problem identification, prognosis diagnosis, treatment, evaluation and follow-up.

\section{References}

Ali, H., \& Purwandi, L. (2016). Indonesia 2020: The urban middle class millenials. PT Alvara Strategi Indonesia.

Ali, H., \& Purwandi, L. (2017). The urban middle-class millenials Indonesia: Financial and online behavioral. PT Alvara Strategi Indonesia.

Ali, M. F. (2014). Contentment (Qona'ah) and its role in curbing social and environmental problems. Islam and Civilisational Renewal ICR Journal, 5(3). https://icrjournal.org/index.php/icr/article/view/435.

Amin, S. M. (2010). Bimbingan dan konseling Islam. Jakarta : Amzah.

Ani, A. (2016). Pemahaman nilai-nilai qona'ah dan peningkatan self esteem melalui diskusi kelompok (studi pada anak-anak yatim panti asuhan Nurul Haq Yogyakarta). Hisbah: Jurnal Bimbingan Konseling dan Dakwah Islam, 13(1), 86-108. https://doi.org/10.14421/hisbah.2016.131-05.

Bambang, S. (2015). Generasi Y: Karakteristik, masalah, dan peran konselor. Makalah Seminar dan Workshop Internasional MALINDO 4, 22-23.

Bernardi, S., \& Pallanti, S. (2009). Internet addiction: A descriptive clinical study focusing on comorbidities and dissociative symptoms. Comprehensive 
Al Halik

Psychiatry,

$50(6)$,

$510-516$.

https://doi.org/10.1016/j.comppsych.2008.11.011.

Budiati, I., Ponco, W., Ayuni, S., Reagen, H., A., Larasaty, P., Setiyawati, N., Pratiwi, A., I., \& Saputri, V. G. (2018). Statistik gender tematik: Profil generasi milenial JAGC | 98 indonesia. Kementerian Pemberdayaan Perempuan dan Perlindungan Anak.

Faqih, A. R. (2001). Bimbingan dan konseling dalam Islam. Yogyakarta: UII Press.

Firmansyah, R. (2018). Relevansi psikoterapi sufistik dalam minhajul abidin ditinjau dari psikoterapi modern rasional emotive behavior therapy. International Seminar on Imam al-Ghazali's Sufism The Role and Contribution of Imam alGhazali on Peace and Harmonious World, 22.

Gamayanti, W. (2016). Gambaran penerimaan diri (self-acceptance) pada orang yang mengalami skizofrenia. Psympathic : Jurnal Ilmiah Psikologi, 3(1), 139152. https://doi.org/10.15575/psy.v3i1.1100.

Hamka. (2015). Tasawuf modern (Cetakan I). Jakarta: Penerbit Republika.

Hasanah, V. N. (2018). Peningkatan penerimaan diri siswa kelas XI SMK SMTI Yogyakarta menggunakan konseling kelompok rational emotive behavior. Jurnal Riset Mahasiswa Bimbingan Dan Konseling, 4(3), 215-225.

Heriyadi, A. (2013). Meningkatkan penerimaan diri (selfacceptance) siswa kelas VIII melalui konseling realita di SMP Negeri 1 Bantarbolang kabupaten Pemalang tahun ajaran 2012/2013 [Other, Universitas Negeri Semarang]. http://lib.unnes.ac.id/17348/.

Ilma, A. N. (2019). Bimbingan agama Islam untuk menguatkan sikap penerimaan diri penerima manfaat di Rumah Pelayanan Sosial Lanjut Usia Pucang Gading Semarang [Undergraduate, UIN Walisongo]. http://eprints.walisongo.ac.id/9999/.

Jalaluddin. (2004). Psikologi agama. Jakarta: PT Raja Grafinda Persada.

Juniman, P. T. (2018). Studi sebut milenial sebagai generasi yang tak bahagia. Diambil 7 Oktober 2020, dari https://www.cnnindonesia.com/gayahidup/20180623204300-277-308441/studi-sebut-milenial-sebagaigenerasi-yang-tak-bahagia.

Keyes, K. L., Shmotkin, D., \& Ryff, C. D. (2002). Optimizing well-beinf: The empirical encounter of two traditions. Journal of Personality and Social Psychology, 82(6), 1007-1022. https://pubmed.ncbi.nlm.nih.gov/12051575/. 
A counseling service for developing the qana'ah attitude of millennial generation in attaining happiness

Koenig, H. G. (2012). Religion, spirituality, and health: The research and clinical implications [Review Article]. ISRN Psychiatry. https://doi.org/10.5402/2012/278730.

Komariah, K. (2019). Efektivitas bimbingan dan konseling islam untuk meningkatkan penerimaan diri pada penyandang tunanetra. Tarbawy: Jurnal Pendidikan Islam, 6(1), 35-42. https://doi.org/10.32923/tarbawy.v6i1.861.

Kusumaningsih, L. P. S. (2017). Penerimaan diri dan kecemasan terhadap status narapidana. Intuisi: Jurnal Psikologi Ilmiah, 9(3), 234-242. https://doi.org/10.15294/intuisi.v9i3.14114.

Mayasari, R. (2014). Religiusitas Islam dan kebahagiaan. Jurnal Al-Munzir, 7(2), 20. http://dx.doi.org/10.31332/am.v7i2.281.

Naja, M. A. (2018). Pandangan masyarakat milenial mengenai agama dan negara [Makalah Program Pascasarjana]. Universitas Sains Al-Qur'an Wonosobo.

Nata, A. (2018). Pendidikan Islam di era milenial. Conciencia, 18(1), 10-28. https://doi.org/10.19109/conciencia.v18i1.2436.

Nuryono, W. (2012). Keefektivan konseling naratif untuk meningkatkan penerimaan diri siswa / Wiryo Nuryono [Thesis, Universitas Negeri Malang]. http://repository.um.ac.id/56685/.

Prayitno. (2017). Layanan bimbingan kelompok dan konseling kelompok yang berhasil. Bogor : Ghalia Indonesia.

Putri, R. K. (2018). Meningkatkan self-acceptance (penerimaan diri) dengan konseling realita berbasis budaya jawa. Prosiding Seminar Nasional Bimbingan Dan Konseling, 2(1), 118-128.

Putu, D.P., \& Ketut, G. S. D. (2017). Pengaruh hedonisme dalam memediasi fashion involvement terhadap perilaku impulse buying pada generasi milenial di Bali. Jurnal Ilmiah Manajemen, 2(2), 311-323. https://doi.org/10.38043/jimb.v2i2.2081.

Rahardjo, W. (2007). Kebahagiaan sebagai suatu prooses pembelajaran. Jurnal Penelitian Psikologi, 12(2), 127-137.

Rahmadani, I., Rizki, R., \& Restya, W. P. D. (2019). Pengaruh sifat qona'ah terhadap perilaku konsumtif pada siswa/i SMA Negeri 3 Banda Aceh. Jurnal Bisnis Dan Kajian Strategi Manajemen, 2(2). https://doi.org/10.35308/jbkan.v2i2.984.

Rakhmat, D. (2010). Tafsir kebahagiaan: Pesan Al-Quran menyikapi kesulitan hidup. Jakarta: Serambi Ilmu Semesta. 
Al Halik

Rifai, M. H. (2018). Mengenal generasi milineal guna kesiapan tenaga pendidik dan dosen di Indonesia. Edudikara: Jurnal Pendidikan Dan Pembelajaran, 3(2), 134-143. https://doi.org/10.32585/edudikara.v3i2.93.

JAGC | 100

Saputro, I., Hasanti, A. F., \& Nashori, F. (2017). Qona'ah pada mahasiswa ditinjau dari kepuasan hidup dan stres. Jurnal IImiah Penelitian Psikologi: Kajian Empiris \& Non-Empiris, 3(1), 11-20. https://doi.org/10.22236/JIPP-24.

Sitorus, M. W., Badrujaman, A., \& Fitri, S. (2019). Pengaruh layanan bimbingan kelompok dengan metode permainan terhadap penerimaan diri siswa. ENLIGHTEN: Jurnal Bimbingan Konseling Islam, 2(1), 18-23. https://doi.org/10.32505/enlighten.v2i1.1215.

Syukur, M. A. (2012). Sufi healing: Terapi dalam literatur tasawuf. Walisongo: Jurnal $\begin{array}{llll}\text { Penelitian Sosial Keagamaan, } & 20(2),\end{array}$ https://doi.org/10.21580/ws.2012.20.2.205.

Tiliouine, H., Cummins, R. A., \& Davern, M. (2009). Islamic religiosity, subjective well-being, and health. Mental health, religion \& culture, 12(1), 55-74. https://doi.org/10.1080/13674670802118099.

Zein, S. A. (2017). Usir gelisah dengan ibadah. Yogyakarta: Diva Press. 